\title{
Formation of dense krill patches under tidal forcing at whale feeding hot spots in the St. Lawrence Estuary
}

\author{
Cédric Cotté ${ }^{1}$, Yvan Simard ${ }^{1,2, *}$ \\ ${ }^{1}$ Institut des Sciences de la Mer, Université du Québec à Rimouski, 310 Allée des Ursulines, PO Box 3300, Rimouski, \\ Québec G5L 3A1, Canada \\ ${ }^{2}$ Institut Maurice-Lamontagne, Fisheries and Oceans Canada, 850 Route de la Mer, PO Box 1000, Mont-Joli, \\ Québec G5H 3Z4, Canada
}

\begin{abstract}
Hydroacoustics (38 and $120 \mathrm{kHz}$ ) was used to estimate the abundance and 3-dimensional distribution of krill and small pelagic fishes at the downstream end of Ile Rouge Bank (St. Lawrence Estuary) over the semidiurnal tidal cycle in July 2002. During the flood, upwelling and strong tidal currents $\left(>1 \mathrm{~m} \mathrm{~s}^{-1}\right)$ forced the krill to aggregate in a patch against the slope of the bank and the mouth of the South Channel. This rich krill patch was then advected in the Laurentian Channel during the ebb. The mean krill density changed from $4 \mathrm{~g} \mathrm{~m}^{-3}$ in the neighbouring scattering layer of the Laurentian Channel to $500 \mathrm{~g} \mathrm{~m}^{-3}$ in the shoaling zone where the patch formed. This aggregation is ascribed to the interaction between the semidiurnal tidal currents, the local topography, and the negative phototactism of krill. The krill scattering layer was composed of Thysanoessa raschi and Meganyctiphanes norvegica. Its upper limit was at a depth corresponding to a light level of $3.1 \times 10^{-1}$ to $1.2 \times 10^{-3} \mu \mathrm{W} \mathrm{cm}{ }^{-2} \mathrm{~nm}^{-1}$ which varied with the turbidity gradient and chlorophyll a concentration. The upper krill scattering layer at this light level was observed to swim down with a mean speed of $5 \mathrm{~cm} \mathrm{~s}^{-1}$ (maximum $13 \mathrm{~cm} \mathrm{~s}^{-1}$ ). The recurrent and tidally predictable availability of rich krill patches makes this part of Ile Rouge bank a highly attractive area for predators such as small pelagic fishes and whales, the latter of which forage on both types of prey during the flood tide.
\end{abstract}

KEY WORDS: Zooplankton · Euphausiids · Patchiness · Whale habitat · Tidal current · Topography

\section{INTRODUCTION}

Zooplankton aggregations, from various origins and time-space scales, are structures that contribute significantly to energy transfer towards higher trophic levels. They constitute important food sources for a large variety of predators such as fishes (Genin et al. 1988, Giske et al. 1990, Kaartvedt et al. 1996, Mackas et al. 1997), rorquals (Simard \& Lavoie 1999) and seabirds (Coyle et al. 1992), and they are an important carbon flux mediator. A trophic network of this kind is found in the Lower St. Lawrence Estuary in summer. How exactly these zooplankton aggregations form is, however, poorly understood. This paper seeks to explain how zooplankton is concentrated in a whale feeding hot spot in the Saguenay-St. Lawrence Marine Park.

Simard \& Lavoie (1999) found that the head of the Laurentian Channel (LC) was the site of the richest krill aggregation yet documented for the NW Atlantic. The mechanisms responsible for the generation of the aggregation act on a large range of scales, from metres to hundreds of kilometres and minutes to years (euphausiid life cycle), and involve dynamic processes linked to local topography (Lavoie et al. 2000). Local aggregations are attributed to smallscale processes which often originate at sites of topographic change. The interaction of vertical migration with bathymetric features such as canyons (Pereyra et al. 1969, Greene et al. 1988), banks (Genin et al. 
1994) or continental slopes (Simard \& Mackas 1989, Robinson \& Gómez-Gutiérrez 1998) often results in zooplankton aggregations. In the main krill aggregation at the head of the LC, local rich patches controlled by the combined effects of tidal currents, topography and krill negative phototactism are found (Lavoie et al. 2000). The negative phototactism of krill and zooplankton is well-known, and variations in light intensity are the 'primarily causal factor' responsible for the initiation and maintenance of vertical movement (Ringelberg 1995).

Light is an essential factor for the vertical distribution of krill at the head of LC, especially under tidal upwelling conditions (Simard et al. 1986). The 'barrier isolume' is a threshold light intensity initiating an avoidance reaction by the organism (Boden \& Kampa 1967, Kampa 1975, Simard et al. 1986, Forward 1988, Gal et al. 1998). This isolume becomes a physical barrier at which euphausiids accumulate (Simard et al. 1986, Forward 1988). Change in underwater light condition affecting this isolume could trigger a variation in the vertical distribution of krill (Kaartvedt et al. 1996).
The size and persistence of the krill aggregation at the head of LC makes this area a particularly attractive site for several species of rorquals from the Atlantic during summer, in their seasonal search for food. The downstream end of the Ile Rouge Bank (see Fig. 1) is 1 of the 3 zones used most intensively by rorquals observed by the whale-watching fleet operating in the Saguenay-St. Lawrence Marine Park (Michaud et al. 1997). This zone is the focus of the present study, the objective of which was to investigate the process of local aggregation formation. The study seeks to test the hypothesis formulated by Lavoie et al. (2000), whereby the combined effects of the semidiurnal tidal currents with the bank topography and the negative phototactism of krill locally concentrate krill in rich patches.

\section{MATERIALS AND METHODS}

Sampling. The study area is located on the southern border of the head of the LC (Fig. 1). It includes the downstream end of Ile Rouge Bank and the South

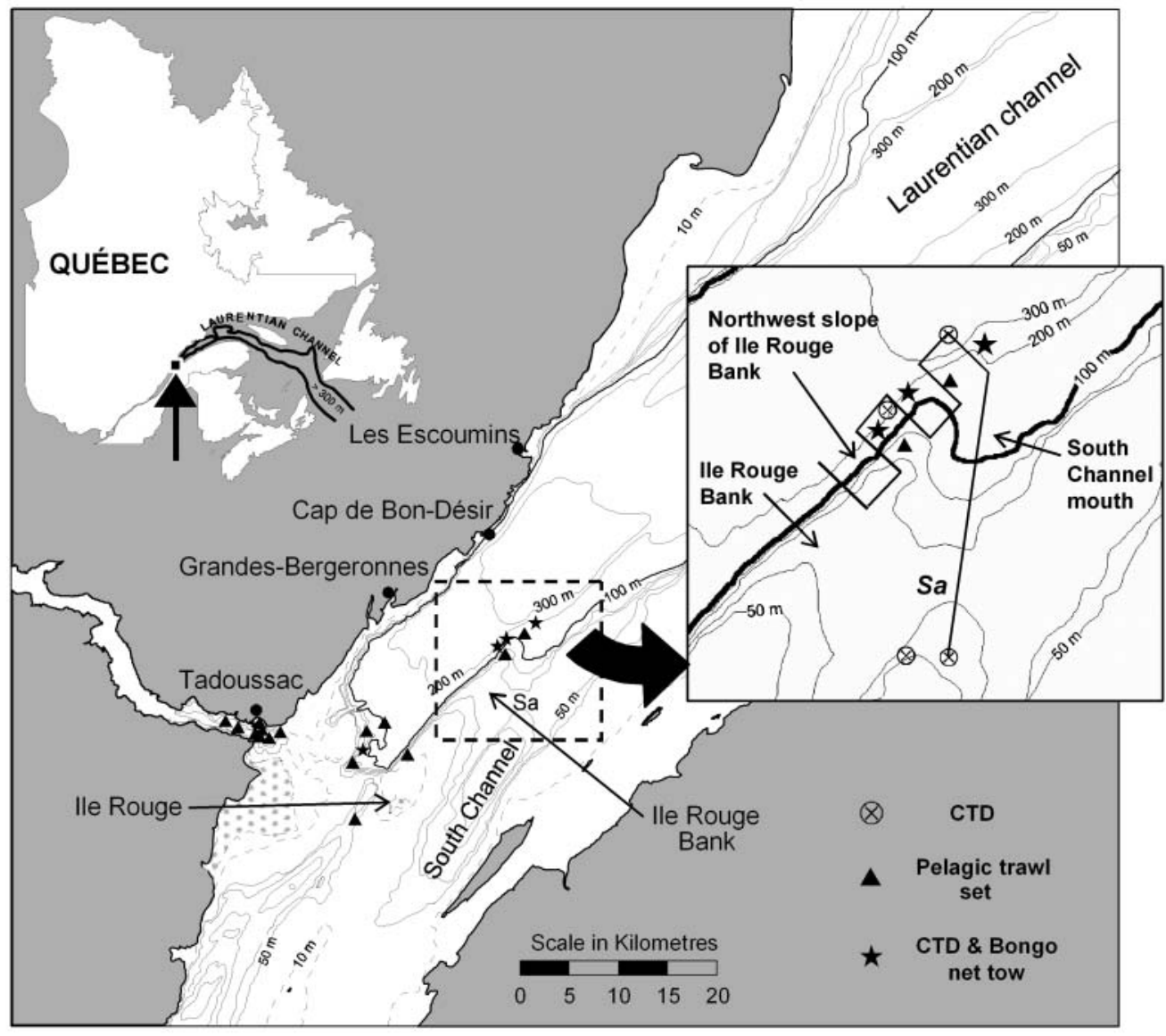

Fig. 1. Study area at head of Laurentian Channel (LC), lower St. Lawrence Estuary, showing acoustic transects and locations of CTD and light transmission profiles, Bongo net tows and pelagic trawl set stations. Sa: South Channel sill 
Channel (SC) mouth. The sampling was carried out on 20, 22 and 23 July 2002, aboard the CCGS FG 'Creed', a $20 \mathrm{~m}$ small waterplane area twin hull vessel (SWATH), and the CCGS 'Calanus II', a $20 \mathrm{~m}$ trawler. A crenellated transect on the bank and a longitudinal transect in SC (Fig. 1, inset) were surveyed at 5 to 6 knots 3 times over the semidiurnal tidal cycle on both 20 and 22 July for acoustical estimation of krill biomass distribution. The survey of the grid took about $2 \mathrm{~h} 30 \mathrm{~min}$. The survey was conducted during daytime only, where krill scattering layers (SL) were at their daytime depth and well separated from epipelagic fishes. Conductivity, temperature (CTD, Sea-Bird Electronics, SBE Seacat 19) and light transmission (Sea Tech, $25 \mathrm{~cm}$ path transmissiometer) profiles were obtained at 4 stations (ringed crosses, inset, Fig. 1). We took 3 additional CTD profiles in association with vertical Bongo net tows on 20 July. Surface water $(2.5 \mathrm{~m})$ was pumped to an on-board CTD equipped with an in situ fluorimeter (Sea-Bird Electronics) to estimate the chlorophyll a concentration at $5 \mathrm{~s}$ intervals along transect. An acoustic Doppler current profiler (ADCP, RDI WH Sentinelle, $300 \mathrm{kHz}$ ) was used to record current flow from 5 to $\sim 150 \mathrm{~m}$ in $2 \mathrm{~m}$ vertical and 4 ping (10 to $12 \mathrm{~s}$ ) horizontal resolution. NOAA-12 and NOAA-16 satellite estimates of sea-surface temperature were obtained from the remote-sensing laboratory of the Maurice Lamontagne Institute (Fisheries \& Oceans Canada, Mont-Joli, Quebec).

The acoustic system was SIMRAD EK60, with 3 hullmounted split-beam transducers operating at $200 \mathrm{kHz}$ $\left(3^{\circ}\right), 120 \mathrm{kHz}\left(3^{\circ}\right)$ and $38 \mathrm{kHz}\left(7^{\circ}\right)$. The ping repetition rate was $1 \mathrm{~s}^{-1}$, which gives a resolution of about $3 \mathrm{~m}$ horizontally at the survey speed. The depth was corrected in real time for the heave through a vessel attitude system (POSMV) providing heave, pitch and roll measurements. Position was obained from the ship's differential global positioning system (DGPS). The acoustic system was calibrated with the standard sphere method for each frequency (Foote et al. 1987).

Ground-truthing samples were collected with a smallmesh (5 mm codend) pelagic trawl (Fipec) and a Bongo net $(333 \mu \mathrm{m}$ mesh). The trawl was monitored with Scanmar netsondes CGM4-SRU-01 (Scanmar AS). The catch was weighted and a random subsample of 250 fishes was measured on board and frozen for laboratory analysis of stomach content. When the catch was composed of zooplankton (krill), a subsample was immediately frozen for laboratory analysis. The Bongo net (stations shown in Fig. 1) was equipped with a flowmeter and a CTD. The total length of euphausiids was measured in the laboratory to the nearest $1 \mathrm{~mm}$. The fish stomach-fullness index (Marchand et al. 1999) was determined for 40 individuals. Stomach content was identified for 20 individuals.
Data analysis. Surface temperature, salinity and chlorophyll a fluorescence concentration maps were computed by ordinary kriging (Chiles \& Delfiner 1999) with a linear variogram without nugget parameter using Surfer (Version 8, Golden Software). The neighbouring search ellipse was elongated along the channel axis to take into account the anisotropy indicated by the surface-temperature satellite map. The irradiance (I) profile was computed according to Arst et al. (1997) as

$$
\begin{gathered}
I=I_{0} \mathrm{e}^{(-0.25 K)} \\
C=-\frac{\ln (t)}{0.25} \\
K=1.168 \sqrt{\left(a^{2}+0.162 a b\right)}
\end{gathered}
$$

where $I_{0}$ is the incident surface irradiance, $K$ is the irradiance attenuation coefficient, and $c$ is the beam attenuation coefficient, $0.25 \mathrm{~m}$ is the transmission path length, $b$ is the diffusion coefficient (equal to $0.8 c \times 0.93$ for turbid waters), $t$ is the light transmission (\%) and $a$ is the absorption coefficient $(a=c-b)$. Surface irradiance was obtained from a PAR photometer (Biospherical Institute) from a nearby oceanographic buoy (IML-4, Fisheries and Oceans Canada, Mont-Joli, Québec). We analysed 3-dimensional (3D) ADCP currents using the bottom as reference. Means were computed for horizontal windows along transect segments.

The Simrad EK60 raw data were converted to HAC standard format (Simard et al. 1997) via CH1 (Simard et al. 1998) and analysed with the echo integration and editing software CH2 (Simard et al. 2000). The echo integration (MacLennan \& Simmonds 1992) was carried out using $120 \mathrm{kHz}$ backscatter on $2 \mathrm{~m}$ vertical and $50 \mathrm{~m}$ horizontal ( 15 pings) bins. Because the large majority of the echoes were from krill, the rare fish schools were not excluded from the echo integration, since their contribution to the total backscatter was negligible. The conversion to biomass unit was done as in Simard \& Lavoie (1999):

$$
\overline{T S}_{W}=\overline{T S}_{N}-10 \log \bar{w}
$$

where $\bar{w}=\sum_{i} \sum_{L j} f_{i L j} w d m_{i}\left(L_{i j}\right)^{k_{i}}$ is the mean weight in $g$ of the 2 krill species (i) caught, computed from the length class ( $L j$ in $\mathrm{mm}$ ) and the dry weight $\left(m_{i}\left(L_{i j}\right)^{k_{i}}\right), \quad m_{i}$ and $k_{i}$ are respectively $7.17 \times 10^{-7}$ and 3.17 for Thysanoessa raschi and $2.9 \times 10^{-7}$ and 3.50 for Meganyctiphanes norvegica, wd is the dry to wet weight conversion factor, equal to $5, f_{i L j}$ the proportion of length class $L_{j}$ of Species $i$ in the combined length-frequency distribution of the 2 species. The average target strength is $\overline{T S}_{N}=10 \log \left(\bar{\sigma}_{b s}\right)$, where $\bar{\sigma}_{b s}=\sum_{i} \sum_{L j} f_{i L j} 10^{\left[\left(q_{N}+r_{N} \log L_{i j}\right) / 10\right]}$ and $q_{N}$ and $r_{N}$ are respec- 
tively -127.45 and 34.85 (Green et al. 1991). The conversion factor, $\overline{T S}_{W}$, was estimated to be $-69.1 \mathrm{~dB} \mathrm{~g}^{-1}$, which is less than $0.1 \mathrm{~dB}$ lower than the conversion factor of Simard \& Lavoie (1999), which was applied here to get the biomass per $\mathrm{m}^{3}(B)$ from the measured volume backscattering coefficient $\left(S_{V}\right)$ :

$$
B=\frac{S_{V}}{\left.10^{(\overline{T S}} / 10\right)}
$$

This was integrated vertically, from $5 \mathrm{~m}$ to the bottom, to get the biomass per $\mathrm{m}^{2}\left(B_{z}\right)$ along the transects. A map was computed for each visit of the transects with ordinary kriging on a $100 \mathrm{~m}$ mesh grid. A spherical model was used for the variogram, taking into account a zonal anysotropy in the LC direction $\left(45^{\circ}\right)$. The search was made by quadrant for an ellipse radius of $3 \mathrm{~km}$ along the LC (to include more than 1 transect) and $0.75 \mathrm{~km}$ across the LC (in proportion to the anisotropy). The total biomass was obtained by multiplying the average biomass for the grid by the estimation area of $25 \mathrm{~km}^{2}$.
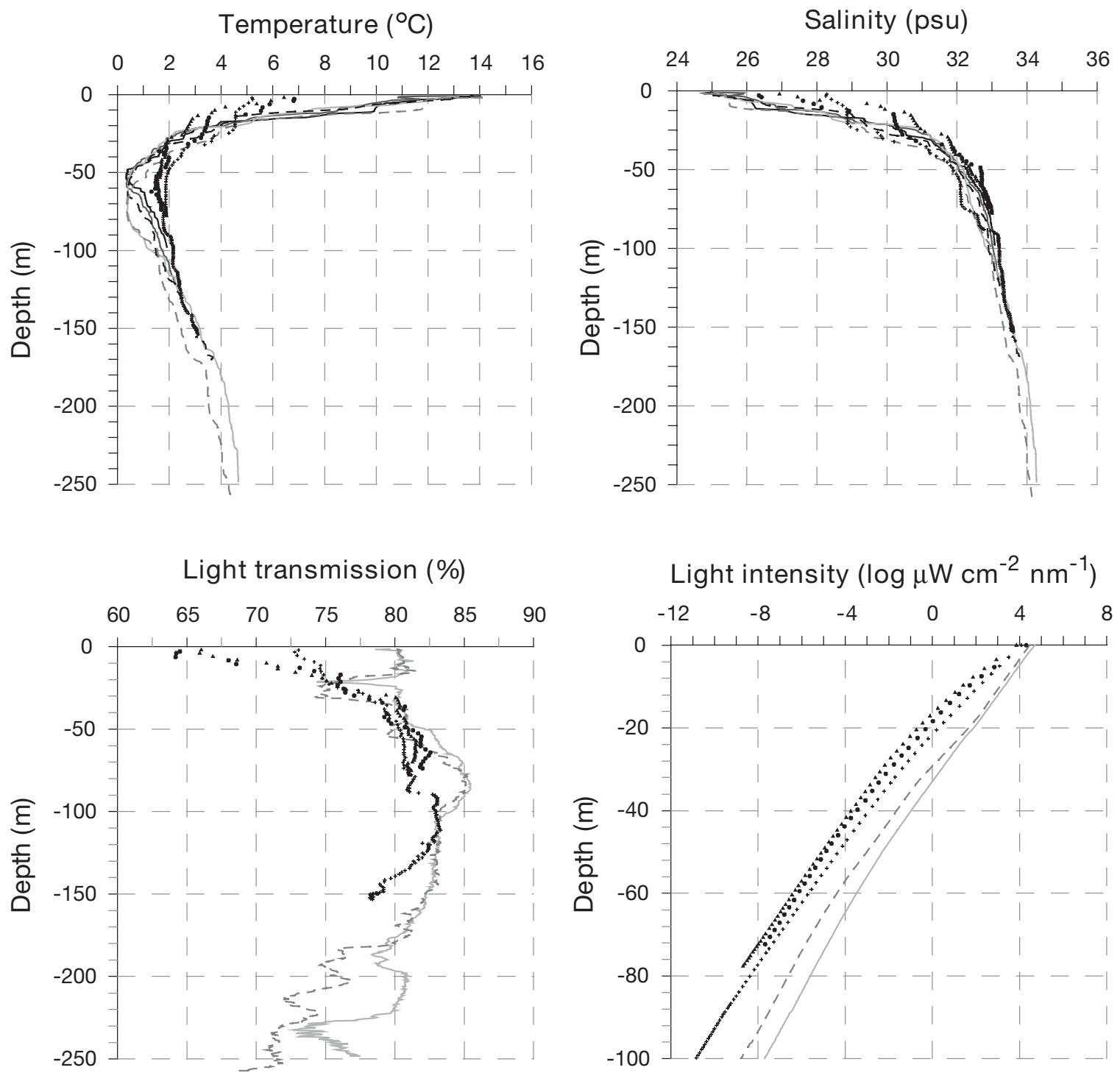

Fig. 2. Temperature, salinity, light transmission and light intensity profiles in study area at stations in Fig. 1. Note different ordinate scale for light intensity 
halocline. The underlying layer is a cold intermediate layer (CIL), delimited by the $2^{\circ} \mathrm{C}$ isotherms and with a salinity of 30 to 33 . This water mass is located between 30 and $\sim 120 \mathrm{~m}$, but its thickness varies with tide and location. The deeper layer is warmer and saltier (>33). The light transmission and corresponding estimated light intensity was higher in the deep LC than in the SC (Figs. 1 \& 2), which gave different average attenuation coefficients (Table 1). These LC profiles also exhibited an attenuation peak at the pycnocline and a higher light transmission at the surface.

\section{Surface temperature and salinity conditions}

The satellite images of surface temperature indicated that the study area was located at the margin of 2 water masses: cold upwelled waters flushing out along the southern coast of the estuary, and warmer waters covering the LC (Fig. 3a). This corresponded closely to measurements at this time at high water (HW) by the FG 'Creed' (Fig. 3b to d). During ebbtide, the warm LC surface waters retreated downstream and the upwelled cold waters invaded the surveyed area (Fig. 3e to j). This was accompanied by an increase in surface fluorescence, especially at the interface of the 2 water masses (Fig. 3d,g,j). Temperature versus salinity graphs (not shown) showed high chlorophyll a concentrations in waters with intermediate temperature and high salinity, corresponding to warmed upwelled waters. The low chlorophyll a concentrations found in the SC sill area corresponded to cold, recently upwelled waters.

\section{D currents structure}

From $2 \mathrm{~h}$ before $\mathrm{HW}$ to HW, currents in the upper $100 \mathrm{~m}$ were 0.5 to $1 \mathrm{~m} \mathrm{~s}^{-1}$, directed towards and over the bank, while the deep currents were about $0.2 \mathrm{~m} \mathrm{~s}^{-1}$ and ran upstream along the bank (Fig. 4a,b). At the SC sill, the forced currents exceeded $1 \mathrm{~m} \mathrm{~s}^{-1}$ in the 50 to

Table 1. Depth of upper limit of krill (Thysanoessa raschi and Meganyctiphanes norvegica) scattering layer $\left(0.5 \mathrm{~g} \mathrm{~m}^{-3}\right)$, average attenuation coefficient $K_{\mathrm{m}}$ (for upper $50 \mathrm{~m}$ ), and corresponding estimated light intensity

\begin{tabular}{|lccc|}
\hline Tidal phase & Depth $(\mathrm{m})$ & $K_{\mathrm{m}}\left(\mathrm{m}^{-1}\right)$ & $\begin{array}{c}\text { Light intensity } \\
\left(\mu \mathrm{W} \mathrm{cm} \mathrm{nm}^{-1}\right)\end{array}$ \\
\hline $\mathrm{HW}+3 \mathrm{~h}$ & 50 & 0.32 & $8.7 \times 10^{-3}$ \\
$\mathrm{LW}-1 \mathrm{~h}$ & 34 & 0.34 & $3.1 \times 10^{-1}$ \\
$\mathrm{LW}-0: 30 \mathrm{~h}$ & 32 & 0.40 & $2.4 \times 10^{-3}$ \\
$\mathrm{LW}$ & 37 & 0.41 & $5.3 \times 10^{-3}$ \\
LW $+1: 30 \mathrm{~h}$ & 40 & 0.39 & $1.2 \times 10^{-3}$ \\
\hline
\end{tabular}

$100 \mathrm{~m}$ layer. From $\mathrm{HW}+1: 30 \mathrm{~h}$ to $2 \mathrm{~h}$ before low water (LW), currents reversed completely for the deep LC waters, but there was no reversal in the upper water column, especially in the SC (Fig. 4c,d). Complete reversal was attained at LW (Fig. 4e,f), when the 0 to $100 \mathrm{~m}$ currents were directed towards the LC and the deep currents ran downstream along the bank at a relatively high speed $\left(0.5 \mathrm{~m} \mathrm{~s}^{-1}\right)$. SC surface currents were strong ( $>1 \mathrm{~m} \mathrm{~s}^{-1}$ ) and began to turn upstream at the SC mouth, as noted by Lavoie et al. (2000) for this tidal phase.

\section{D krill structure}

From HW - $1 \mathrm{~h}$ to $\mathrm{HW}+1.5 \mathrm{~h}$, the krill in the LC were distributed in a thick layer between 100 and $150 \mathrm{~m}$ with an average density of $4 \mathrm{~g} \mathrm{~m}^{-3}$ (Fig. 5a). A thin and less dense layer, at depths of 50 to $70 \mathrm{~m}$, was also present (Fig. 5a, arrows). On the edge of the bank, the scattering layer was constrained by the topography and formed a high-density thin layer against the slope and top of the bank, and the SC mouth. The density of this thin layer varied between 50 and $100 \mathrm{~g} \mathrm{~m}^{-3}$ and reached $500 \mathrm{~g} \mathrm{~m}^{-3}$ in some areas. This aggregation was occasionally accompanied by fish schools. The vertically integrated biomass revealed a patch (>300 $\mathrm{g} \mathrm{m}^{-2}$ ) elongated against the $100 \mathrm{~m}$ bathymetric contour. This was lower $\left(<100 \mathrm{~g} \mathrm{~m}^{-2}\right)$ in the shallow area of the bank and SC. From HW $+1.5 \mathrm{~h}$ to LW $-2 \mathrm{~h}$, the areal biomass was generally lower and high densities were only present in LC and at the SC mouth (Fig. 5b). After LW - $2 \mathrm{~h}$, the dense thin layers in shallow areas disappeared, the krill layer in LC became diffuse (75 to $175 \mathrm{~m}$ depth), and the richest areal densities were found offshore with some dense patches $\left(\sim 25 \mathrm{~g} \mathrm{~m}^{-3}\right)$. The thin and weak layer around $50 \mathrm{~m}$ was still present. Around LW, the upper limit of the krill scattering layer was up to $18 \mathrm{~m}$ shallower than at $\mathrm{HW}+3 \mathrm{~h}$ in the downstream part of the surveyed area (Table 1, Fig. 5c).

The total biomass for the $25 \mathrm{~km}^{2}$ of the estimated area varied between 5875 and 2140 t over the 6 visits of 20 and 22 July. On 20 July, the biomass peaked at HW and decreased by a factor of 2 during the ebb. On 22 July, the peak biomass was 2.5 times lower than on 20 July. It was maximum after $\mathrm{HW}(\mathrm{HW}+0.5$ to $2 \mathrm{~h})$, rather than exactly at HW.

The thin and weak krill scattering layer between 32 and $50 \mathrm{~m}$ corresponded exactly with a layer with negative vertical speeds as measured by the ADCP (Fig. 5: vertical current profiles). The speeds averaged ca. $-5 \mathrm{~cm} \mathrm{~s}^{-1}$ and could reach $-13 \mathrm{~cm} \mathrm{~s}^{-1}$. This layer was mainly concentrated in the LC and the SC mouth, and its speed decreased over the bank and the SC sill (for details see Cotté 2004). 
Temperature $\left({ }^{\circ} \mathrm{C}\right)$
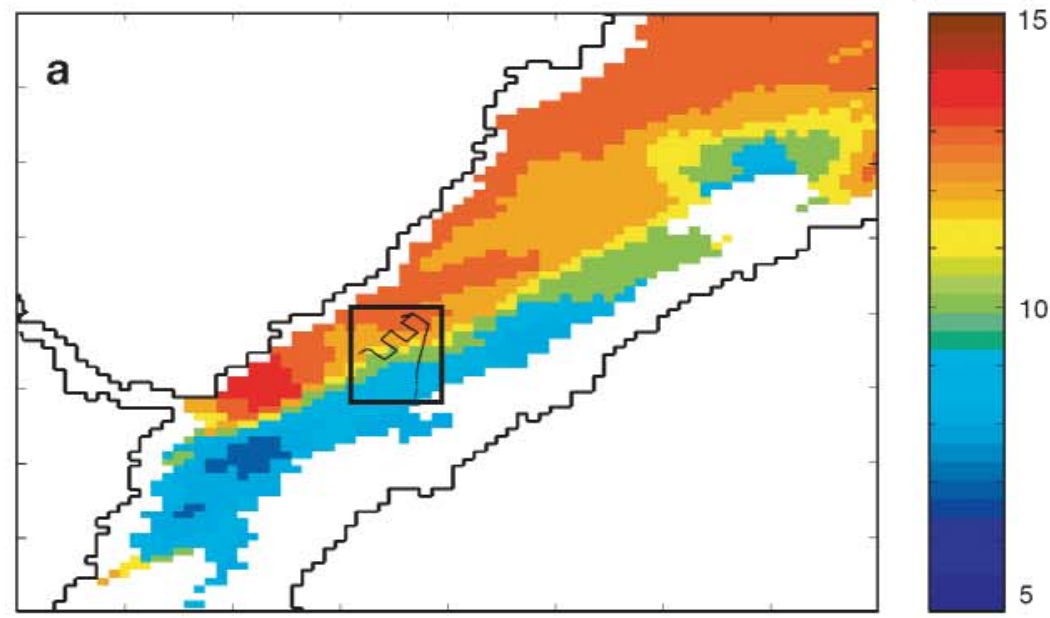

Temperature
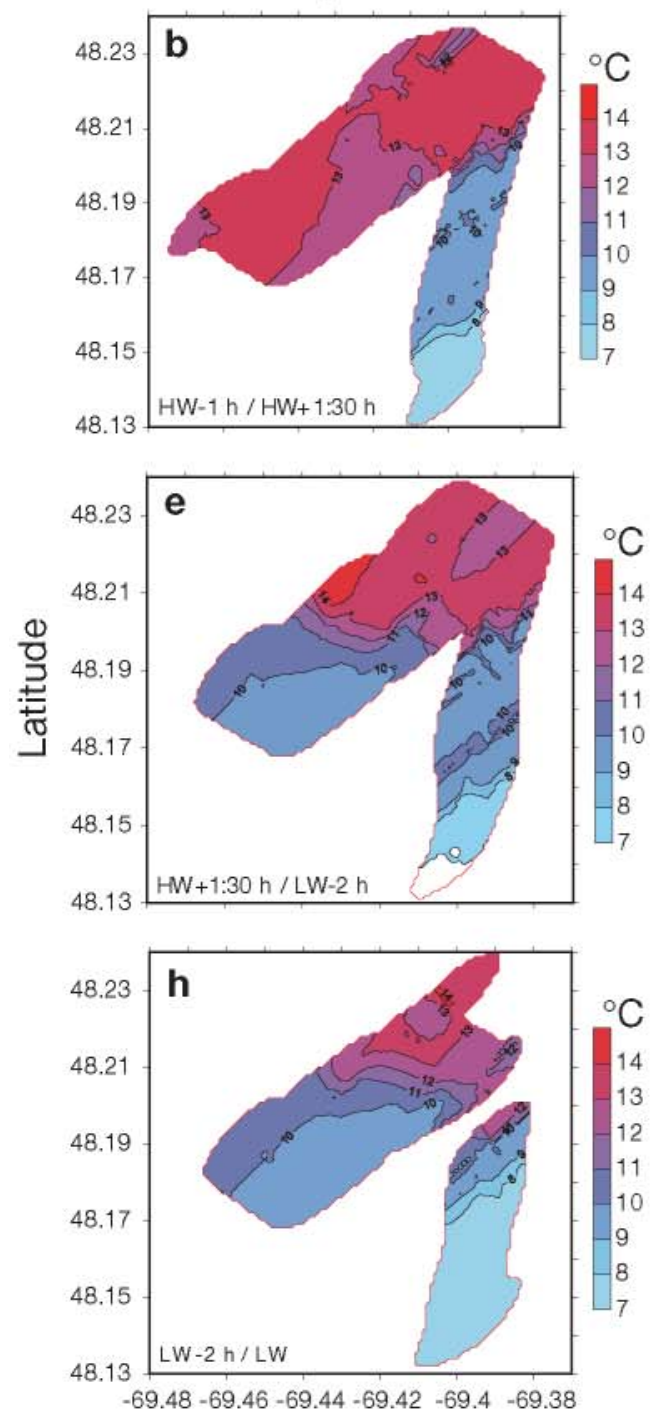

Salinity
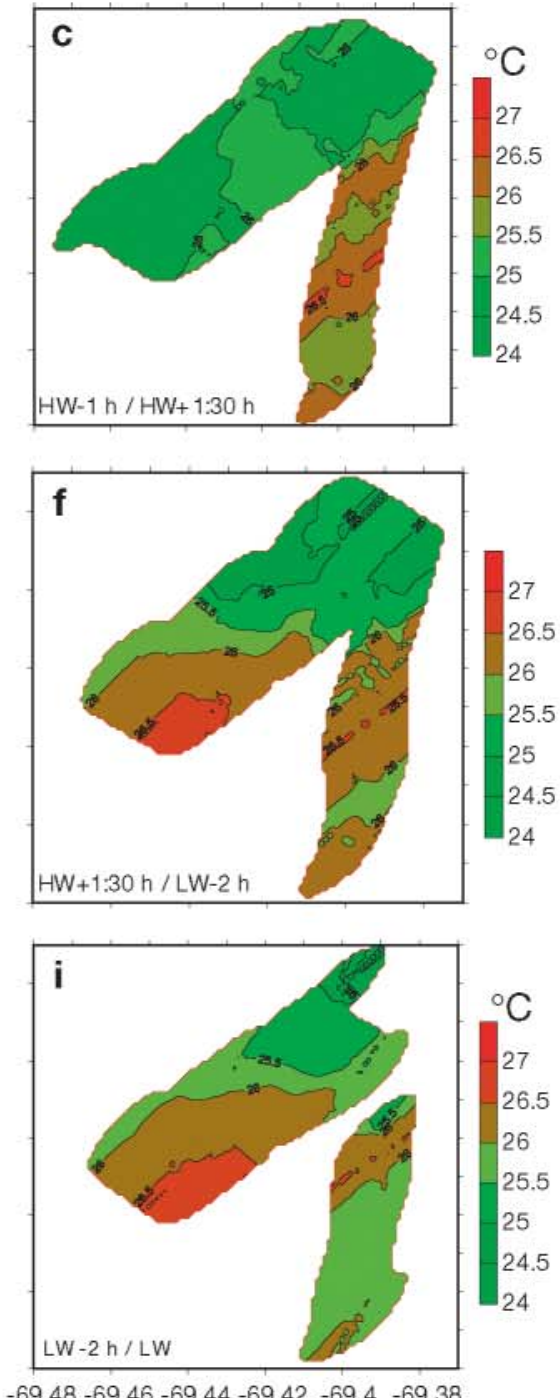

$-69.48-69.46-69.44-69.42-69.4-69.38$
Fluorescence
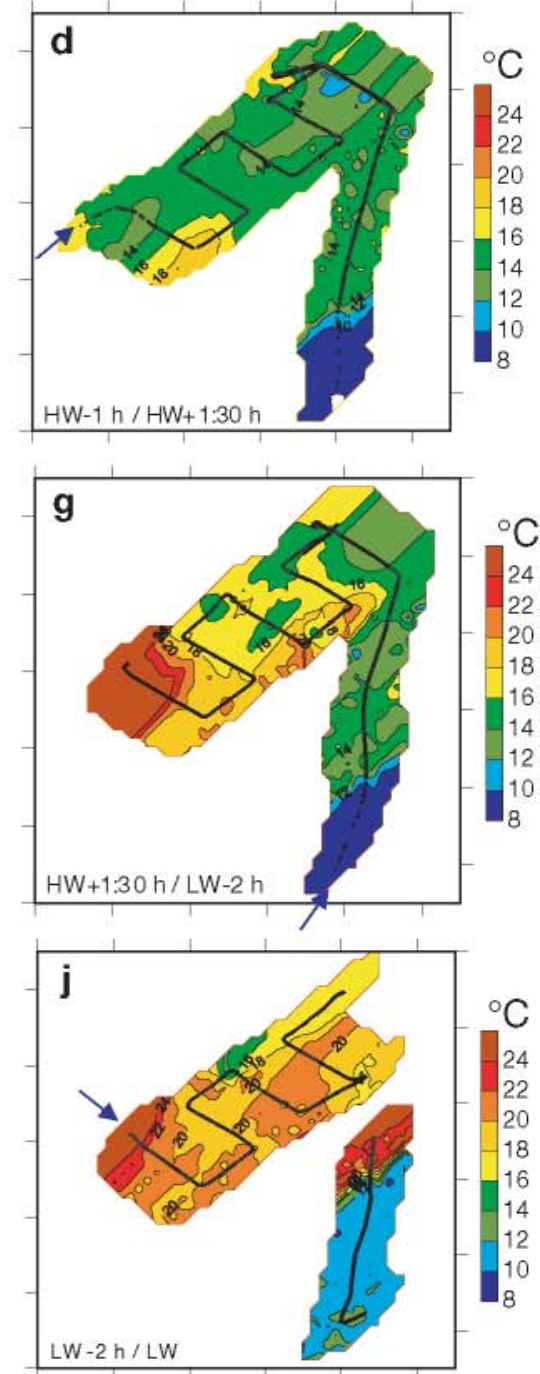

$-69.48-69.46-69.44-69.42-69.4-69.38$

\section{Longitude}

Fig. 3. NOAA thermal satellite image of head of Laurentian Channel on 20 July, 12:51 h US Eastern Daylight Time (EDT) at high water, indicating (a) study area, $(\mathrm{b}, \mathrm{e}, \mathrm{h})$ surface temperature $\left({ }^{\circ} \mathrm{C}\right),(\mathrm{c}, \mathrm{f}, \mathrm{i})$ salinity and $(\mathrm{d}, \mathrm{g}, \mathrm{j})$ fluorescence (relative units) from $10: 46 \mathrm{~h}$ $(\mathrm{b}-\mathrm{d})$ to $17: 57 \mathrm{~h}(\mathrm{~h}-\mathrm{j})$; blue arrow at beginning of track (black line) indicates survey direction. HW: high water; LW: low water 
The upper limit of the krill layer in the area varied from 32 to $50 \mathrm{~m}$ and corresponded to a narrow range of light intensities, from $3.110^{-1}$ to $1.210^{-3} \mu \mathrm{W}$ $\mathrm{cm}^{-2} \mathrm{~nm}^{-1}$ (Table 1). In the shallow area, the high light attenuation in surface water (Fig. 2) accompanied the shallower upper limit of the krill scattering layer.

\section{Zooplankton and small pelagic fish analysis}

As in the previous studies at the head of the LC (Simard \& Lavoie 1999, Simard et al. 2002), the zooplankton biomass was largely dominated by euphausiids, with length-frequency distributions corresponding to only 2 yr old individuals (Berkes 1976) for the 2 species Thysanoessa raschi (mode at $\sim 26 \mathrm{~mm}$ ) and Meganyctiphanes norvegica (mode at $\sim 33 \mathrm{~mm}$ ) (for further details see Cotté 2004). The majority of the fishes caught were 2+ capelin Mallotus villosus (Bailey et al. 1977). Capelin stomach contents showed a predominance of copepods (mainly Calanus finmarchicus) and (in lower abundance) the 2 euphausiids species. The capelin stomach fullness index and the average occurrence of euphausiids in the stomach contents were higher at the end of the flood tide (for details see Cotté 2004).

\section{DISCUSSION}

\section{Krill aggregation and patchiness}

The krill biomass in the study area was generally high and patchy, with intermittent dense concentrations, similar to those previously reported for the St. Lawrence Estuary (Simard \& Lavoie 1999) or the rich krill aggregations of the Antarctic (Hewitt \& Demer 1993). Occasionally values exceeded $600 \mathrm{~g} \mathrm{~m}^{-2}$ or $500 \mathrm{~g} \mathrm{~m}^{-3}$. This krill concentration hot spot corresponds to the fringe of the main aggregation core located off Les Escoumins-Cap de Bon Désir (Simard \& Lavoie 1999). Rorquals use this area intensively, as testified by the activity of the whale-watching fleet there (Michaud et al. 1997) and tracking of a tagged fin whale in the area during flood tide (Fig. 3b1 in Simard et al. 2002).

The decrease of biomass from 20 to 22 July was probably related to the retreat of the main aggregation core downstream. The tidal displacement of the richest part of the aggregation did not reach the Ile Rouge Bank and SC entrance during this period.

The krill aggregation at the downstream end of the Ile Rouge Bank was caused by the interaction of tidal currents with the topography. The 3D current structure observed corresponds closely to that obtained from a high-resolution 3D circulation model of the area by
Saucier \& Chassé (2000) and hourly prediction of currents by Lavoie et al. (2000). During flood tide, the LC krill aggregation is pushed towards the bank and the SC entrance by tidal currents, when particular hydrodynamic conditions divert them towards the SC (Lavoie et al. 2000). This results in krill 'piling-up' against the bank. The upwelling raises and compresses the krill scattering layer vertically. Thin and very dense krill layers are then formed close to the bottom at the slope of the bank and behind the SC sill, which results in an elongated rich patch along the $100 \mathrm{~m}$ contour. The currents then reverse during ebb tides and the aggregation built up on the shallow area during flood is flushed towards the LC, where currents shear vertically and flow is downstream at depth. The scattering layer becomes more diffuse, but still contains dense patches. This interaction of currents with sloping topography has been observed elsewhere in several coastal upwelling areas (Simard et al. 1986, Simard \& Mackas 1989, Mackas et al. 1997) and appears to be a fundamental component of the concentration process at the head of the LC (Lavoie et al. 2000), and probably elsewhere in the St. Lawrence system.

This recurrent 'piling-up' of krill against Ile Rouge Bank and the SC entrance during flood tide, and its subsequent flushing during ebb tide, contributes significantly to small-scale krill patchiness in the larger aggregation at the head of the LC. The highest densities can reach $500 \mathrm{~g} \mathrm{~m}^{-3}$, or about 4500 Thysanoessa raschi or 1500 Meganyctiphanes norvegica $\mathrm{m}^{-3}$. The few hundred metres-wide, dense patches are preserved during flushing by the ebb tide, and may persist for a few hours to days (Genin et al. 1994). Such patches observed in the krill scattering layers of the Gulf of St. Lawrence were attributed to concentrations during diel vertical migration in the surface layer at night (Sameoto 1983). This hypothesis does not explain horizontal patchiness. The concentration process we observed at the downstream end of the Ile Rouge Bank shows that patch creation proceeds in a different way and involves interaction of currents with topography (Simard et al. 1986, Simard \& Mackas 1989, Genin et al. 1994). Tracking of this process over a semidiurnal tidal cycle reveals the formation of these patches, the origins of which often remain unknown (Haury et al. 1978, Hamner 1988). The dynamics of this patchiness was probably the source of the more patchy distribution of krill we observed on 22 July compared to 20 July.

\section{Depth-maintenance and negative phototactism of krill}

Physical processes are not sufficient to explain the observed variation in aggregation. The reaction of krill to underwater light levels is also a probable key factor (as proposed by Lavoie et al. 2000), since it controls 
a $\mathrm{HW}-1 \mathrm{~h}$ to $\mathrm{HW}+1: 30 \mathrm{~h}$

Speed:

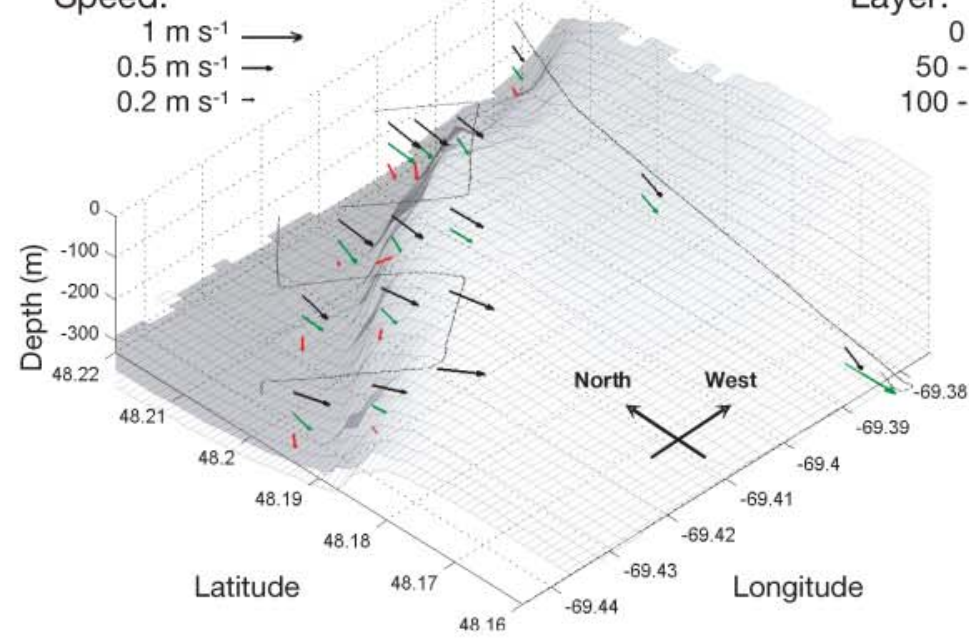

\section{c $\mathrm{HW}+1: 30 \mathrm{~h}$ to $\mathrm{LW}-2 \mathrm{~h}$}

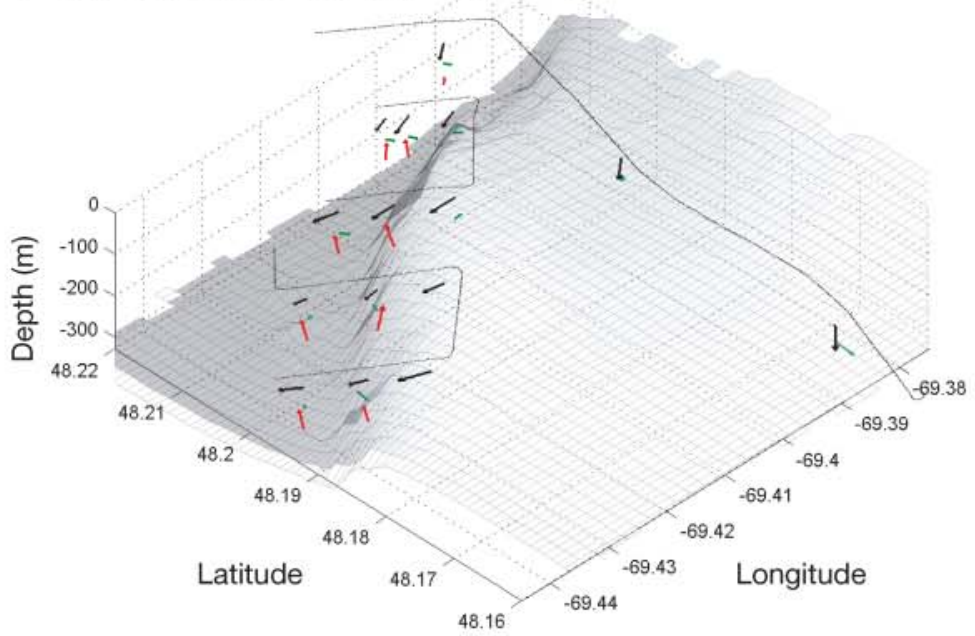

\section{e $L W-2 h$ to $L W$}

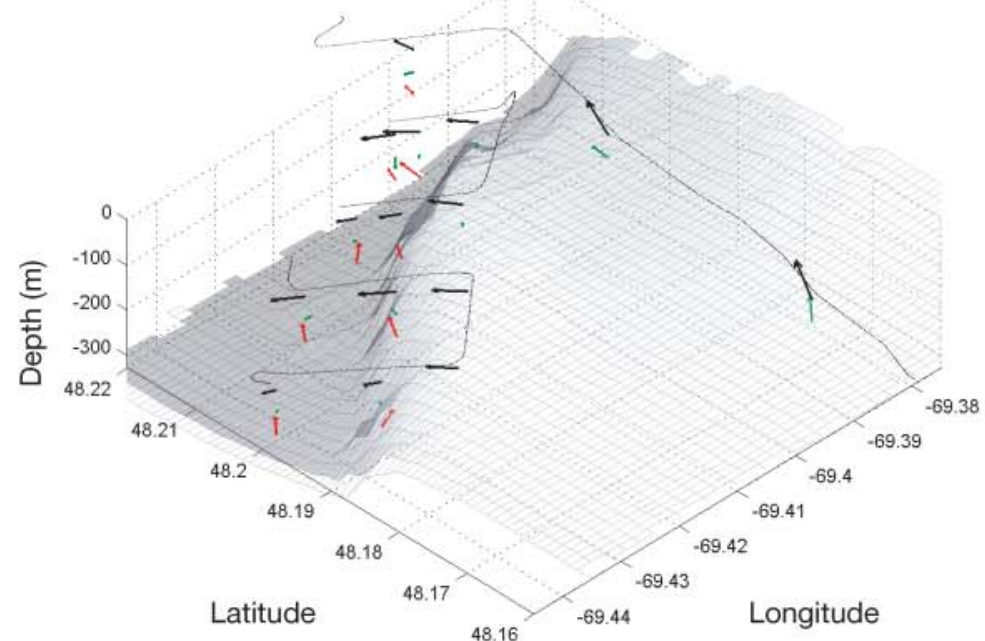

b

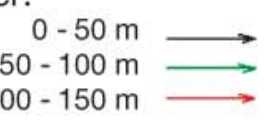

Speed:

$1 \mathrm{~m} \mathrm{~s}^{-1} \longrightarrow$ $0.5 \mathrm{~m} \mathrm{~s}^{-1} \rightarrow$ $0.2 \mathrm{~m} \mathrm{~s}^{-1}-$
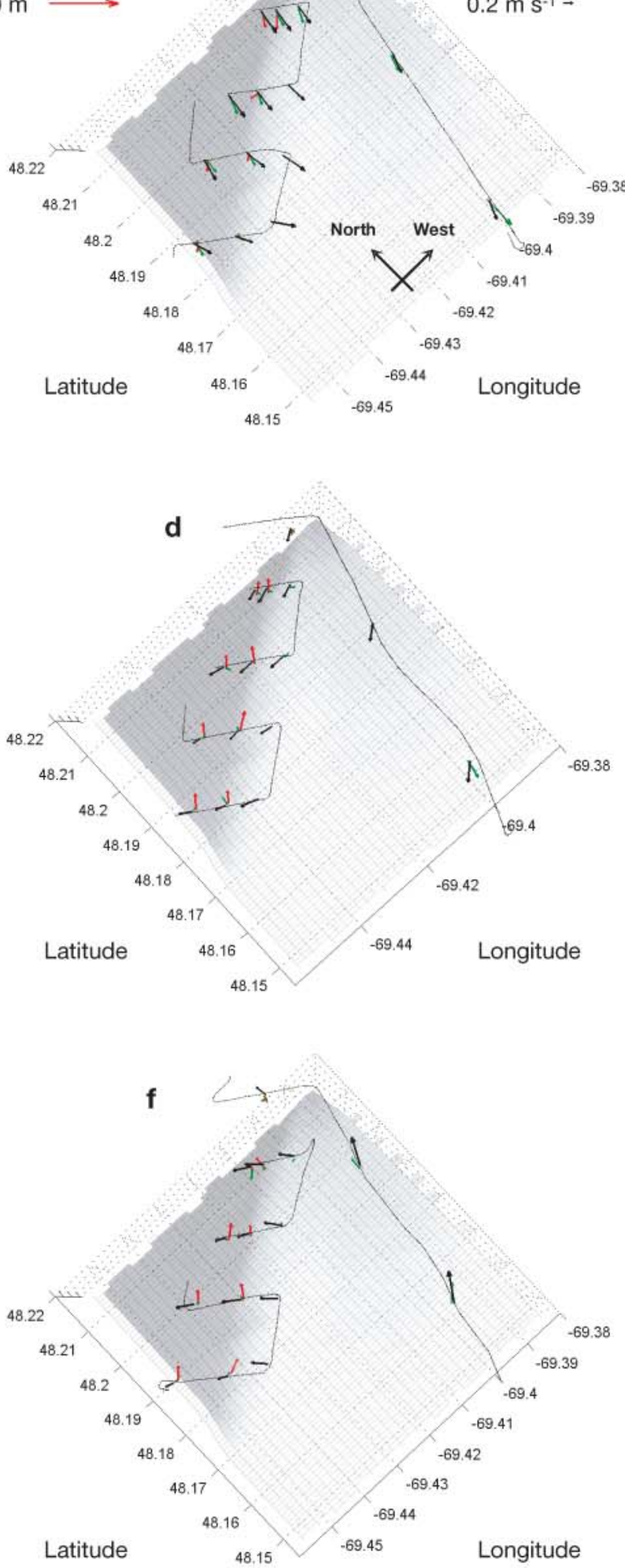

Fig. 4. Three-dimensional structure of currents along transects from acoustic Doppler current profiler (ADCP) on (a,b) 20 July at HW -1 h to HW + 1:30 h, (c,d) 2 h later, and (e,f) 2 h before LW to LW. a,c,e: perspective view; b, d,f: plan view 


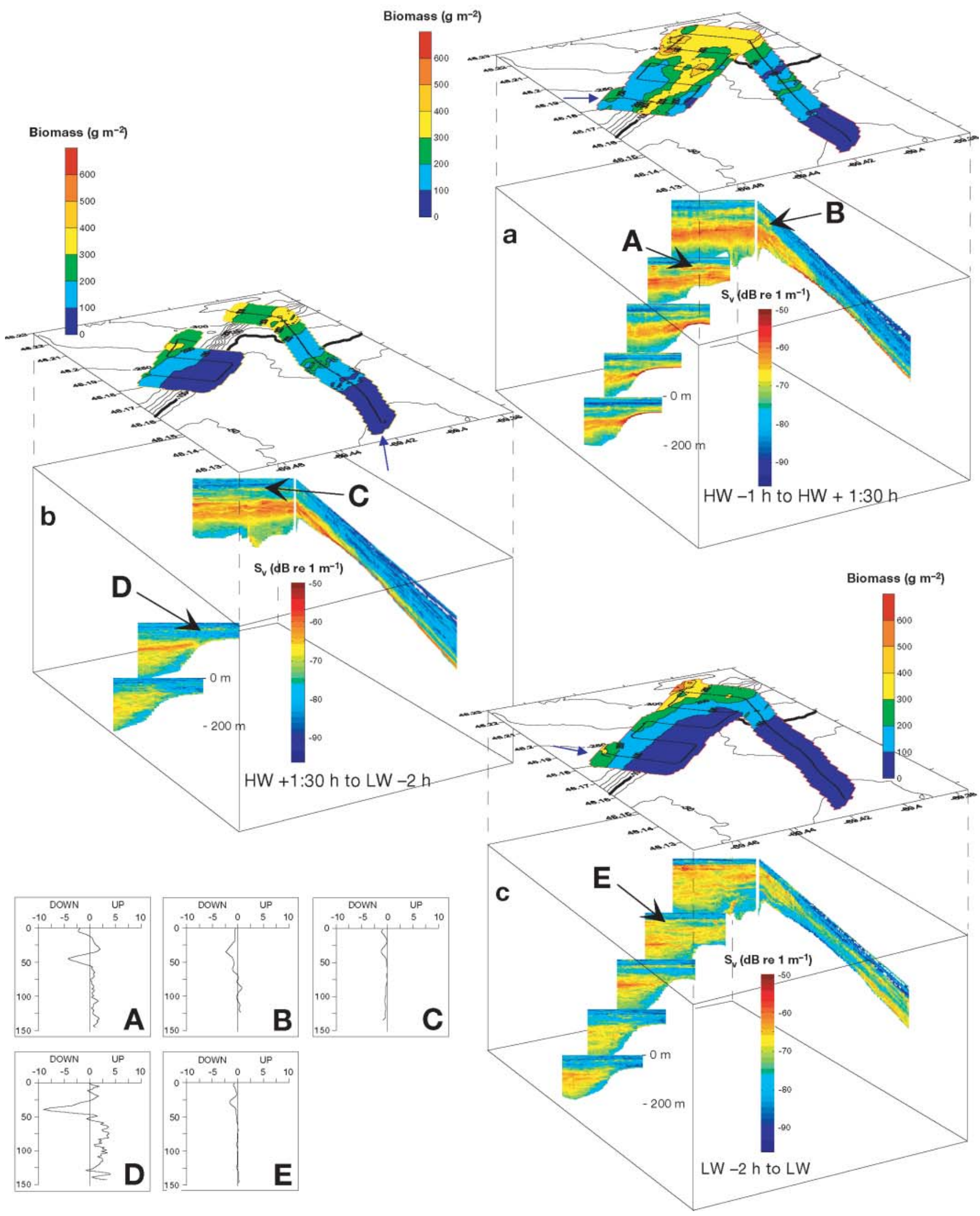

Fig. 5. Thysanoessa raschi and Meganyctiphanes norvegica. (A-C) Three-dimensional structure of krill biomass $\mathrm{m}^{-3}$ (volume backscattering strength, $\mathrm{S}_{\mathrm{v}}\left[\mathrm{dB}\right.$ re $\left.1 \mathrm{~m}^{-1}\right]$ ), map of biomass $\mathrm{m}^{-2}$ integrated over water column at different phases of tide, and profiles of average vertical currents $\left(\mathrm{cm} \mathrm{s}^{-1}\right)$ from ADCP at locations arrowed A-E. Blue arrow at beginning of track indicates survey direction. Graphs A-E: $y$-axis is depth $(\mathrm{m})$ and $x$-axis is vertical speed in $\mathrm{cm} \mathrm{s}^{-1}$ 
the vertical distribution of euphausiids. The upper light-level limit of the krill scattering layer was found between $3.1 \times 10^{-1}$ and $1.2 \times 10^{-3} \mu \mathrm{W} \mathrm{cm} \mathrm{cm}^{-1}$. This is slightly higher than the range of in situ light intensity observed for Meganyctiphanes norvegica $\left(10^{-4}\right.$ to $10^{-5} \mu \mathrm{W} \mathrm{cm}{ }^{-2} \mathrm{~nm}^{-1}$, Boden \& Kampa 1967, Kampa 1976, Onsrud \& Kaartvedt 1998). However, a scattering layer tracked during a solar eclipse followed an isolume of $2 \times 10^{-1} \mu \mathrm{W} \mathrm{cm} \mathrm{cm}^{-2} \mathrm{~nm}^{-1}$ (Kampa 1975), and Sameoto (1980) observed a light intensity of $10^{-2}$ to $10^{-4} \mu \mathrm{W} \mathrm{cm} \mathrm{cm}^{-2}$ $\mathrm{nm}^{-1}$ for a multispecies krill scattering layer in the Gulf of St. Lawrence. The light intensities measured at the top of the scattering layer in the present study were for a different species, Thysanoessa raschi, which is smaller and lives higher in the water column than $M$. norvegica (Simard et al. 1986), as corroborated by the catches and the higher backscattering at $120 \mathrm{kHz}$ compared to $38 \mathrm{kHz}$ of the upper scattering layers (Chu et al. 1993). The depth of this light-level limit was found to vary as a function of area as well as upper limit of the scattering layer, probably because of the turbidity gradient and the shadowing effect of the phytoplankton patches, as described by Kaartvedt et al. (1996) for the ascent of the krill scattering layer when encountering a front.

An intriguing scattering layer with negative vertical speed was observed at a depth of about $45 \mathrm{~m}$ on 20 July. This layer is unlikely to be the result of a physical process alone. No density anomaly or related current shear were observed in the water profiles at that depth. The vertical speed did not present a gradient, but a sharp peak corresponding to the scattering layer. This plunging layer did not correspond to the strong, high-frequency internal wave which propagates in the area at the end of the ebb tide (Lavoie et al. 2000, Saucier \& Chassé 2000), since this affects the whole water column and not just a single layer. According to its depth, this scattering layer was probably composed of Thysanoessa raschi. The observed vertical speed averaged $5 \mathrm{~cm} \mathrm{~s}^{-1}$, which is larger than the sinking speeds of euphausiids (Kils 1981) but close to the sustained swimming speed reported for Meganyctiphanes norvegica (Buchholz et al. 1995, Liljebladh \& Thomasson 2001) and slightly lower than burst speeds over 2 min (Hardy \& Bainbridge 1954). Higher speeds, closer to our observed maximum, have been noted for $M$. norvegica (Tarling et al. 2001) that can reach $15 \mathrm{~cm} \mathrm{~s}^{-1}$ (Kils 1981). These values correspond to 4 body lengths $\mathrm{s}^{-1}$, which would give about $12 \mathrm{~cm} \mathrm{~s}^{-1}$ for T. raschi. The possible explanation is that a T. raschi scattering layer is pushed towards its isolume barrier (Boden \& Kampa 1967, Kampa 1971, 1976) and strongly reacts by swimming downwards, and this is detected by the ADCP. However, at the observed swimming speed, the layer would reach the bottom $(200 \mathrm{~m})$ in less than $1 \mathrm{~h}$; the reason for the persistence of this layer over a longer part of the tidal cycle could be that the organisms stop swimming downwards and reduce their energy expense when they reach a comfortable light level, are then borne back upwards by upwelling current, and then again swim downwards. Similar downwards swimming behaviour may also result from advection over deeper waters of krill concentrations trapped over shallows during the previous part of the tidal cycle.

\section{Prey aggregations and availability to predators}

The negative phototactism of krill results from visual predator avoidance (Zaret \& Suffern 1976, Gliwicz 1986). Fish schools are common close to krill aggregations (Genin et al. 1988, Giske et al. 1990, Mackas et al. 1997, Robinson et al. 1998). Although fish schools were rare in the study area during the survey, previous studies showed that capelin are frequently present in the upper water column at the head of the LC (Simard et al. 2002). The few fish schools observed in this study were located above the scattering layer, but also at depth close to the shoaling aggregation during flood tide, as also reported by Simard et al. (2002). Capelin stomach contents show that they feed on krill and copepods (as described by Vesin \& Leggett 1981), especially at the end of the flood tide (also noted by Ménard 1998), when dense concentrations are found at shallow depths. These tidal dynamics differ from those during the usual period of twilight predation often found in other environments (e.g. Clark \& Levy 1988). In the LC, the tide 'sets the table'. This is also true for larger predators such as whales, which come to feed on these predictable local tidal aggregations at the end of the flood tide (Michaud \& Giard 1997), when they can harvest dense concentrations of both krill and capelin efficiently with minimum effort. These rich patches persist for at least a few hours, after being flushed to the LC, where they are still attractive to feeding whales. The advantage of such aggregations for the negatively phototactic krill is not evident, since aggregated krill are more attractive to bulk-feeding predators such as baleen whales. The concentration of prey into smaller areas may limit encounters with random searching predators on small- to meso-scales, but is unlikely to be very advantageous, since predators have developed strategies to find such feeding hot spots. The advantage of avoiding visual predators by negative phototactism probably outweighs the drawback of being concentrated in upwelling currents. As in schooling fishes, warning signals of close predator threats from conspecific neighbours, especially bioluminescent emissions, may benefit aggregated krill. Their aggregation along sloping bottoms where upwelling occurs certainly helps to maintain them in regions with higher production potential. 


\section{CONCLUSION}

This work has shown that the downstream end of the Ile Rouge Bank is a site of regular intense aggregation and dispersion of krill over the semidiurnal tidal cycle. These small-scale dynamics are driven by the interaction of tidal currents with local topography and the negative phototactism of krill. The flooding currents advect a part of the larger local krill aggregation towards the bank, where the organisms concentrate in a thin layer close to the bottom during tidal upwelling. The in situ light level plays a key role in this process, whereby the euphausiids tend to stay below a barrier isolume, to which they react by actively swimming downwards at maximum speed. The predictive and recurrent high krill densities make this area attractive for pelagic fishes and rorquals, which feed on both the krill and the fishes. This dynamics at the downstream end of Ile Rouge bank is a good example of the complex processes generating the patchiness of the krill aggregation at the head of the Laurentian Channel and that of zooplankton in general.

Acknowledgements. We thank Y. Samson, S. Chartrand, D. Beaulieu, C. Lesveque, S. Guittard, A. Godin, N. Roy and the crews of the CCGS FG 'Creed' and 'Calanus II' for their assistance with data collection and analysis. We are indebted to P. Larouche for supplying the satellite thermal images and guidance in the processing of light transmission data. Comments from a reviewer helped improve the English. This work was supported by Fisheries and Oceans Canada, the DFO chair in marine acoustics applied to resources and ecosystem at ISMER, NSERC grant 249977-02 to Y.S. and ISMER and Quebec Ocean support to C.C.

\section{LITERATURE CITED}

Arst H, Mäekivi S, Lukk T, Herlevi A (1997) Calculating irradiance penetration into water bodies from the measured beam attenuation coefficient. Limnol Oceanogr 42: 379-385

Bailey RFJ, Able KW, Leggett WC (1977) Seasonal and vertical distribution and growth of juvenile and adult capelin (Mallotus villosus) in the St. Lawrence estuary and western Gulf of St. Lawrence. J Fish Res Board Can 34: 2030-2040

Berkes F (1976) Ecology of euphausiids in the Gulf of St. Lawrence. J Fish Res Board Can 33:1894-1905

Boden BP, Kampa EM (1967) The influence of natural light on the vertical migrations of an animal community in the sea. Symp Zool Soc 19:15-26

Buchholz F, Buchholz C, Reppin J, Fischer J (1995) Diel vertical migrations of Meganyctyphanes norvegica in the Kattegat: comparison of net catches and measurements with Acoustic Doppler Current Profilers. Helgol Meeresunters 49:849-866

Chiles JP, Delfiner P (1999) Geostatistics: modeling spatial uncertainty. Wiley series in probability and statistics, Wiley, New York

Chu D, Foote KG, Stanton TK (1993) Further analysis of tar- get strength measurements of Antarctic krill at 38 and $120 \mathrm{kHz}$ : comparison with deformed cylinder model and inference of orientation distribution. J Acoust Soc Am 93: $2985-2988$

Clark CW, Levy DA (1988) Diel vertical migration by juvenile sockeye salmon and the antipredation window. Am Nat 131:271-290

Cotté C (2004) Dynamique d'agrégation du krill et des espèces fourragères à un site d'observation des rorquals, à l'extrémité du banc de l'île Rouge, dans l'estuaire du Saint-Laurent. MSc thesis, Université du Québec à Rimouski, Québec

Coyle KO, Hunt GL Jr, Decker MB, Weingartner TJ (1992) Murre foraging, epibenthic sound scattering and tidal advection over a shoal near St. George Island, Bering Sea. Mar Ecol Prog Ser 83:1-14

Foote KG, Knudsen HP, Vestnes G, MacLennan DN, Simmonds EJ (1987) Calibration of acoustic instruments for fish density estimation: a pratical guide. Int Counc Explor Sea Coop Res Rep 144

Forward RB (1988) Diel vertical migration: zooplankton photobiology and behaviour. Oceanogr Mar Biol Annu Rev 26:361-393

Gal GL, Ellis R, Rudstam LG, Mohammadian AM (1998) Light and diel vertical migration: spectral sensitivity and light avoidance by Mysis relicta. Can J Fish Aquat Sci 56: 311-322

Genin A, Haury L, Greenblatt P (1988) Interactions of migrating zooplankton with shallow topography: predation by rockfishes and intensification of patchiness. Deep-Sea Res I 35:151-175

Genin A, Greene C, Haury L, Wiebe P and 5 others (1994) Zooplankton patch dynamics: daily gap formation over abrupt topography. Deep-Sea Res I 41:941-951

Giske J, Aksnes DL, Baliño BM, Kaartvedt S and 5 others (1990) Vertical distribution and trophic interactions of zooplankton and fish in Masfjorden, Norway. Sarsia 75:65-81

Gliwicz MZ (1986) Predation and the evolution of vertical migration in zooplankton. Nature 320:746-748

Greene CH, Wiebe PH, Burczinski J, Youngbluth MJ (1988) Acoustical detection of high-density krill demersal layers in the submarine canyon off Georges Bank. Science 241: 359-361

Greene CH, Stanton TK, Wiebe PH, McClatchie S (1991) Acoustic estimates of Antarctic krill. Nature 349:110

Hamner WM (1988) Behavior of plankton and patch formation in pelagic ecosystems. Bull Mar Sci 43:752-757

Hardy AC, Bainbridge R (1954) Experimental observations on the vertical migrations of plankton animals. J Mar Biol Assoc UK 33:409-448

Haury LR, McGowan JA, Wiebe PH (1978) Patterns and processes in the time-space of plankton distributions. NATO Conf Ser IV 3:277-327

Hewitt RP, Demer DA (1993) Dispersion and abundance of Antartic krill in the vicinity of Elephant Island in the 1992 austral summer. Mar Ecol Prog Ser 99:29-39

Kaartvedt S, Melle W, Knutsen T, Skjoldal HR (1996) Vertical distribution of fish and krill beneath water of varying optical properties. Mar Ecol Prog Ser 136:51-58

Kampa EM (1971) Photoenvironment and sonic scattering. In: Farquhar B (ed) Proceedings of an International Symposium on Biological Sound Scattering in the Ocean Maury Center for Ocean Science, US Government Printing Office, Washington, DC, p 51-59

Kampa EM (1975) Observations of a scattering layer during the total solar eclipse, 30 June 1973. Deep-Sea Res I 22: $417-423$ 
Kampa EM (1976) Photoenvironment and vertical migrations of mesopelagic marine animal communities. In: De Coursey PJ (ed) Biological rhythms in the marine environment. Belle W Baruch Library in Marine Sciences, University of South Carolina Press, Columbia, p 257-272

Kils U (1981) Swimming behaviour, swimming performance and energy balance of Antarctic krill Euphausia superba. Biomass Sci Ser 3:1-121

Lavoie D, Simard Y, Saucier FJ (2000) Aggregation and dispersion of krill at channel heads and shelf edges: the dynamics in the Saguenay-St. Lawrence Marine Park. Can J Fish Aquat Sci 57:1853-1869

Liljebladh B, Thomasson MA (2001) Krill behaviour as recorded by acoustic Doppler current profilers in the Gullsmarsfjord. J Mar Syst 27:301-313

Mackas DL, Kieser R, Saunders M, Yelland DR, Brown RM, Moore DF (1997) Aggregation of euphausiids and Pacific hake (Merluccius productus) along the outer continental shelf off Vancouver Island. Can J Fish Aquat Sci 54: 2080-2096

MacLennan DN, Simmonds EJ (1992) Fisheries acoustics. Chapman \& Hall, London

Marchand C, Simard Y, Gratton Y (1999) Concentration of capelin (Mallotus villosus) in tidal upwelling fronts at the head of the Laurentian channel in the St. Lawrence estuary. Can J Fish Aquat Sci 56:1832-1848

Ménard N (1998) Répartition spatiale et structure des bancs de poissons pélagiques dans une aire d'alimentation des cétacés de l'estuaire du Saint-Laurent. MSc thesis, Université Laval, Ste-Foy, Québec

Michaud R, Giard J (1997) Les rorquals communs et les activités d'observations en mer des cétacés dans l'estuaire maritime du Saint-Laurent en 1994-1996. 1: Étude de l'utilisation du territoire et évaluation de l'exposition aux activités d'obesrvation en mer à l'aide de la télémétrie VHF. Final report to Parks Canada, Canadian Heritage Department, Ottawa. Groupe de recherche et d'éducation sur le milieu marin (GREMM), Québec

Michaud R, Bédard C, Mingelbier M, Gilbert MC (1997) Les activités d'observation en mer des cétacés dans l'estuaire maritime du Saint-Laurent 1985-1996: une étude de la répartition spatiale des activités et des facteurs favorisant la concentration des bateaux sur les sites d'observations. Final report to Parks Canada, Canadian Heritage Department, Ottawa. Groupe de recherche et d'éducation sur le milieu marin (GREMM), Québec

Onsrud MSR, Kaartvedt S (1998) Diel vertical migration of the krill Meganyctiphanes norvegica in relation to physical environnement, food and predators. Mar Ecol Prog Ser 171:209-219

Pereyra WT, Pearcy WG, Carvey FE Jr (1969) Sebastopodes flavidus, a shelf rockfish feeding on mesopelagic fauna, with consideration of the ecological implications. J Fish Res Board Can 26:2211-2215

Ringelberg J (1995) Changes in light intensity and diel vertical migration: a comparison of marine and freshwater environments. J Mar Biol Assoc UK 75:15-25

Editorial responsibility: Otto Kinne (Editor-in-Chief), Oldendorf/Luhe, Germany
Robinson CJ, Gómez-Gutiérrez J (1998) Daily vertical migration of dense deep scattering layers related to the shelfbreak area along the northwest coast of Baja California, Mexico. J Plankton Res 20:1679-1697

Sameoto DD (1980) Relationships between stomach contents and vertical migration in Meganyctiphanes norvegica, Thysanoessa raschii and T. inermis (Crustacea Euphausiacea). J Plankton Res 2:129-143

Sameoto DD (1983) Euphausiid distribution in acoustic scattering layers and its significance to surface swarms. J Plankton Res 5:129-143

Saucier FJ, Chassé J (2000) Tidal circulation and buoyancy effects in the St. Lawrence estuary. Atmos-Ocean 28: 505-556

Simard Y, Lavoie D (1999) The rich krill aggregation of the Saguenay-St. Lawrence Marine Park: hydroacoustic and geostatistical biomass estimates, structure, variability and significance for whales. Can J Fish Aquat Sci 56: 1182-1197

Simard Y, Mackas DL (1989) Mesoscale aggregations of euphausiid sound scattering layers on the continental shelf of Vancouver Island. Can J Fish Aquat Sci 46: 1238-1249

Simard Y, de Ladurantaye R, Therriault JC (1986) Aggregation of euphausiids along a coastal shelf in an upwelling environment. Mar Ecol Prog Ser 32:203-215

Simard Y, McQuinn I, Montminy M, Lang C, Miller D, Stevens C, Wiggins D, Marchalot C (1997) Description of the HAC standard format for raw and edited hydroacoustic data Version 1.0. Can Tech Rep Fish Aquat Sci 2174

Simard Y, McQuinn I, Montminy M, Samson Y, Lang C, Stevens C, Miller D (1998) CH1, Canadian hydroacoustic data analysis tool 1, user's manual, Version 2.0. Can Tech Rep Fish Aquat Sci 2256

Simard Y, McQuinn I, Montminy M, Lang C and 7 others (2000) CH2, Canadian hydroacoustic data analysis tool 2, user's manual, Version 2.0. Can Tech Rep Fish Aquat Sci 2332

Simard Y, Lavoie D, Saucier FJ (2002) Channel head dynamics: capelin (Mallotus villosus) aggregation in the tidally driven upwelling system of the Saguenay-St. Lawrence park's whale feeding ground. Can J Fish Aquat Sci 59: 197-210

Tarling GA, Matthews JBL, David P, Guerin O, Buchholz F (2001) The swarm dynamics of northern krill (Meganyctiphanes norvegica) and pteropods (Cavolinia inflexa) during vertical migration in the Ligurian Sea observed by an Acoustic Doppler Current Profiler. Deep-Sea Res I 48: 1671-1686

Vesin JP, Leggett WC (1981) Feeding ecology of Capelin (Mallotus villosus) in the estuary and western Gulf of St. Lawrence and its multispecies implications. Can J Fish Aquat Sci 38:257-267

Zaret TN, Suffern SJ (1976) Vertical migration in zooplankton as a predator avoidance mechanism. Limnol Oceanogr 21:804-813

Submitted: March 12, 2004; Accepted: September 7, 2004

Proofs received from author(s): March 2, 2005 